\title{
AZ AGROERDÉSZET SZEREPE AZ ERDŐFELÚJÍTÁSBAN ÉS A NÖVEKVŐ FAANYAGIGÉNY KIELÉGÍTÉSÉBEN
}

\author{
Kovács Klaudia - Vityi Andrea - Szalay Dóra
}

\begin{abstract}
Absztrakt: A faanyag iránti növekvő igény kielégítése miatt egyre nagyobb nyomás nehezedik az erdőgazdálkodásra. A fásított területekről származó dendromassza kihozatal mennyiségi és minőségi paramétereinek javításában az agroerdészeti gyakorlatok alkalmazásának is jelentős szerepe lehet a jövőben. Az erdei köztes termesztés hagyományos gyakorlat a Kárpát medencében. Hazai tapasztalatok és vizsgálati eredmények e gyakorlat pozitív hatását igazolják a talaj-mikroklímára, valamint a faegyedek növekedési paramétereire, mely jelentősen befolyásolhatja az erdőfelújítások sikerességét. Ugyanakkor a szabad terület hasznosításával egyéb célokat is szolgálva (takarmánytermesztés, ökoszisztéma-szolgáltatások) a felújítás erőforráshatékonysággal és gazdasági hozadékkal is párosul.
\end{abstract}

\begin{abstract}
The growing demand for wood has put growing pressure on forest management. The use of agroforestry practices can also play a significant role in the future by improving the quantitative and qualitative parameters of dendromass yields from wooded areas. Intermediate cultivation in forest stands is a traditional practice in the Carpathian Basin. Domestic experiences and test results confirm the positive effect of this practice on the soil microclimate and on the growth parameters of the tree stands, which can significantly affect the success of forest regeneration. At the same time, by utilizing the free space for other purposes (fodder production, ecosystem services), renovation is coupled with resource efficiency and economic benefits.
\end{abstract}

Kulcsszavak: erdőfelújítás, dendromassza, agroerdészet, LER, köztestermesztés, faanyag

Keywords: reforestation, dendromass, agroforestry, LER, alley cropping system, wood

\section{Bevezetés}

Az európai faanyag igények növekedése (Jonsson et al, 2018)(Eurostat, 2018) és az intenzív mezőgazdasági technológiák több ponton ütköznek a környezetvédelem érdekeivel. Az időjárási szélsőségek, vízhiány, ár-és belvizek gyakoribb elöfordulása, a talajerózió, a mütrágyahasználatból eredő talajvízszennyezés, valamint a biodiverzitás csökkenése kedvezőtlenül befolyásolja mind a természetes vegetációt, mind a termelés minőségi és mennyiségi paramétereit.

Magyarországon az erdőterületek aránya közel 22,1\% (Nébih, 2016), a mezőgazdasági hasznosítás pedig közel 57,4\%-os területarányt mutat (KSH, 2018). Mivel az erdőterületek növelésének lehetősége korlátozott, ugyanakkor jelentös mezőgazdasági területtel rendelkezünk, érdemes olyan földhasználati módokra fókuszálni, melyek a mezőgazdasági gyakorlatok és a fatermesztés kombinációjával egyaránt segítheti a klímaváltozás hatásainak csökkentését és a faanyag iránti növekvő igény kielégítését.

\section{A mezőgazdasági gyakorlat és a fatermesztés kombinációja}

Az „agroerdészeti” vagy „,agrár-erdészeti” rendszerekben tudatosan kombinálják a fás vegetációt (fák, bokrok) mezőgazdasági haszonnövény kultúrákkal és/vagy állattartással. Az agrárerdészeti rendszerek a társított fajok ill. fajták, a telepítési struktúra és az alkalmazott technológia függvényében rendkívül változatos 
megjelenésüek lehetnek. Magyarországon e hagyományokkal bíró földhasználati gyakorlat elöfordulása többek között az intenzív növénytermesztés elterjedésével az utóbbi évtizedekben jelentősen csökkent, ugyanakkor a klímaadaptációban és a termelésbiztonság növelésében betöltött szerepe miatt a gazdálkodók részéről újra nő az érdeklődés mind a hagyományos, mind a modern agroerdészeti gazdálkodási rendszerek iránt (Kovács et al. 2017) (Vityi et al. 2018).

Főbb típusai közül a növényi biomassza termelés szempontjából hazánkban elsősorban a növényi védősávok (pl. part menti és mezővédö erdősávok), a haszonnövény termesztéssel kombinált faülttetvények és a fasorokkal ill. fás sávokkal kombinált köztestermesztéses rendszerek juthatnak jelentősebb szerephez.

\section{Az agroerdészet szerepe a növekvő faanyagigény kielégítésében, a mezőgazdaság szemszögéből}

A felsorolt földhasznosítási módok közös jellemzője, hogy megfelelő technológia alkalmazása mellett a rendszer elemei kölcsönösen kedvezően hatnak egymásra, és ebből adódóan ökológiai és gazdasági vonatkozásban is fenntarthatóbb gazdálkodás valósulhat meg (IAASTD). Az agroerdészeti rendszerek sok szempontból tudnak kedvező hatást kifejteni a gazdálkodás minőségére. Megfelelő technológia alkalmazásával kedvező megtérülési mutatókkal rendelkeznek: akár 30-40\%-os termés-növekedést is eredményezhetnek azáltal, hogy a fás vegetáció védi a veteményt az időjárás szélsőségeitől, kedvezőbb mikroklímát teremt, növeli a biodiverzitást és ugyanazon területen a mezőgazdasági termény hozamát kiegészítő fatermést is produkál (Gál 1963; Dupraz et al, 2005). Hazai és nemzetközi gyakorlati példák sora igazolja, hogy a mezőgazdasági rendszerben jelen lévő fák pozitív hatása a produkció mennyiségi és minőségi javulásában egyaránt megmutatkozik (Suliman et al. 2012) (Abdul 2013) (Daniel et al. 2017). A különböző növénykultúrák kombinálásával a jövedelemszerzés lehetőségeit is bővítheti az agroerdészet, hiszen a szántóföldi kultúrák kombinálhatók többek között sarjaztatásos vagy hengeresfa ültetvényekkel vagy gyümölcsösökkel (beleértve a csonthéjasokat) is. A rendszerek méhlegelőként is hasznosíthatók a megfelelő mézelő fajok változatos telepítésével. A gazdasági és ökológiai előnyök mellett kiemelendő a rekreációs érték is, hiszen a tájképi változatosság a turizmus és a helyi lakosság életminősége szempontjából is kedvező.

\section{Az agroerdészet szerepe a növekvő faanyagigény kielégítésében, az erdőgazdálkodás szemszögéből: az erdőfelújítás támogatása agrárerdészeti módszerekkel}

A fásított területekről származó dendromassza kihozatal mennyiségi és minőségi paramétereinek javításában az agroerdészeti gyakorlatok alkalmazásának jelentős szerepe lehet a jövőben. Az erdőfelújításokban alkalmazott köztestermesztés hagyományos gyakorlat a Kárpát medencében. Hazai rendszerekben végzett vizsgálatok eredményei és a megfigyelések e gyakorlatnak a talaj-mikroklímára, 
valamint a faegyedek növekedési paramétereire gyakorolt pozitív hatását igazolják, mely jelentősen befolyásolhatja az erdősítések sikerességét.

Magyarországi erdőfelújításban alkalmazott köztestermesztéses kísérleti rendszerben és a kontrollként használt csemeteállományban komplex hozam - és termőhelyvizsgálatokat végeztünk, ezek eredményeit az alábbiakban mutatjuk be.

- A facsemeték a köztestermesztéses rendszerben jobb növekedést produkáltak. A köztes kultúra - Magyarországon jellemzően kukorica-, ha jól választjuk meg a távolságokat, versenyhelyzetet teremt és részlegesen árnyékol, így ösztönzi a növekedésre a fiatal faegyedeket. Tekintettel a két terület azonos adottságaira, a köztestermesztéses terület faegyedeinek szignifikánsan erőteljesebb növekedésében a kedvezőbb mikroklímának meghatározó szerepet tulajdonítottunk (Vityi-Kovács 2018).

- Az agroerdészeti területen a talaj hő- és vízháztartása jóval kiegyensúlyozottabb volt a kontrolhoz képest. A pozitív hatás különösen erősen érvényesült aszályos időszakokban; az aszálykár okozta veszteség a kontroll területen jelentős volt, míg a köztes erdei termesztés területén nem tapasztaltunk kiveszést. A köztes terület napi átlaghőmérsékletei arid időszakban szignifikánsan kisebbek voltak, mint a kontroll terület értékei (Vityi-Kovács 2017).

- Az agroerdészeti rendszer csemeteállományában vadkár gyakorlatilag nem volt tapasztalható (Vityi-Kovács 2017, 2018).

\section{A termőterület hatékonyabb és egyben fenntartható kihasználása}

Az agroerdészeti gyakorlatok különböző típusai egyre ismertebbé és elterjedtebbé válnak manapság a gazdálkodói körökben. Ennek oka részben az, hogy az agroerdészeti területek változatosabb felépítésüek, mint az egyoldalú mezőgazdasági gazdálkodási formák (pl. ültetvény gazdálkodás, nagyüzemi állattartás, monokultúrás földmüvelés), így a bevétel diverzifikálásával növelik a termelésbiztonságot. A produkció tekintetében a hagyományos módszerek kombinálásával létrehozható rendszerek összehasonlítására az egyoldalú gazdálkodási típusokkal egy speciális arányszám szolgál, ez a föld egyenérték arány (Land Equivalent Ratio - LER), mely alapján megállapítható az agroerdészeti rendszer komparatív rentabilitása (Abdullahi et al. 2017).

$$
\begin{gathered}
L E R=\sum_{i=0}^{n} \frac{\text { agroerdészeti rendszerből származó fakihozatal }}{\text { tiszta állományból származó fakihozatal }}+ \\
+\frac{\text { agroerdészeti rendszerből származó köztesnövény produktum }}{\text { monokultúrából származó haszonnövény produktum }}
\end{gathered}
$$

Ez az arányszám a köztes rendszer 1 hektárnyi területére eső produktumát hasonlítja össze az azonos biomassza kategóriába tartozó egynemü kultúrák fajlagos hozamával (1. ábra). Ez az összefüggés kiválóan alkalmazható olyan rendszerekben, ahol a fás vegetáció és a köztes növénykultúra kombinációja fennmarad a gazdálkodás végéig, ám az erdőfelújításban alkalmazott köztesnövény- termesztés esetében módosítani szükséges a számítási módszert. 


\section{1. ábra: A föld egyenérték arány}

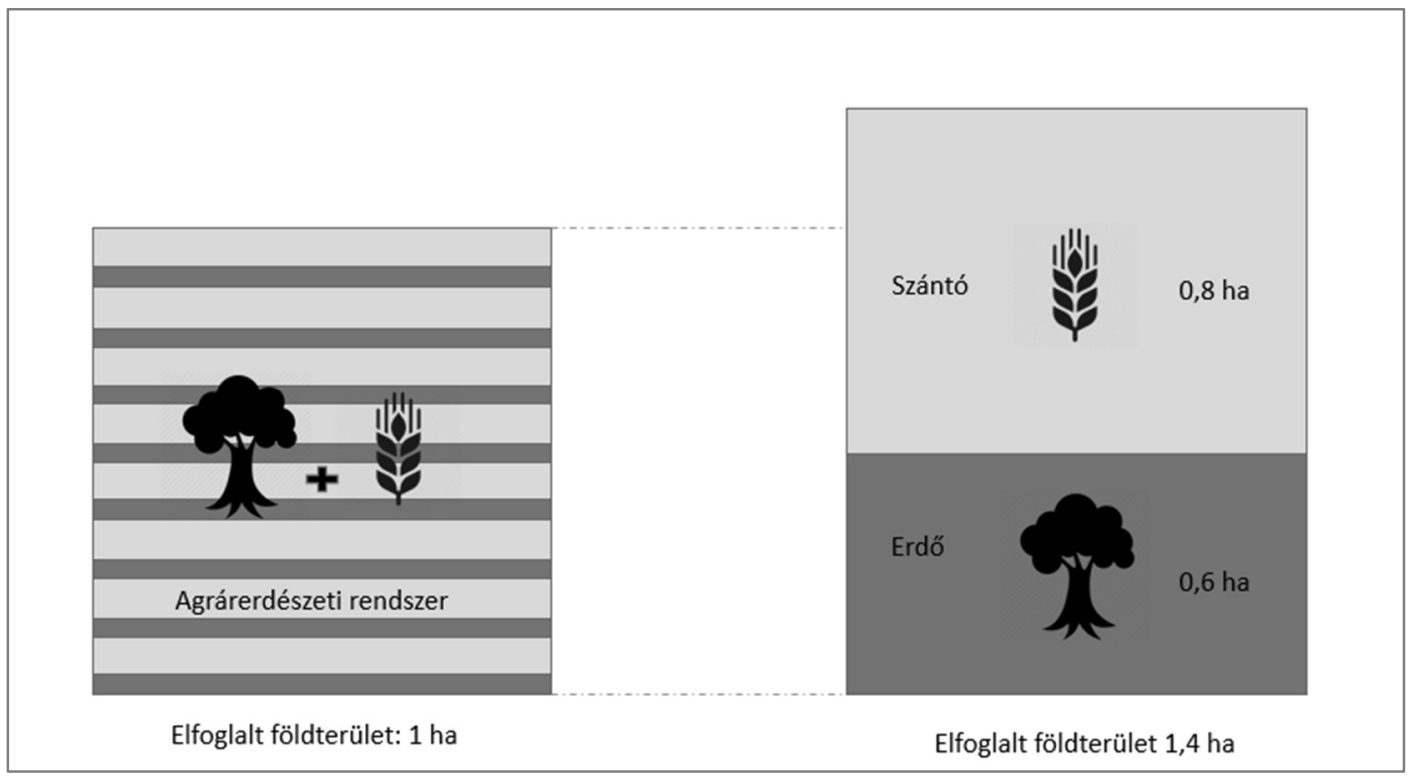

Forrás: Vityi et al., 2018, (Dupraz 2010) nyomán

A különböző növényi kultúrákkal rendelkező termőterületek hozamának összehasonlítására alkalmas LER mutató az erdei köztesnövény-termesztéses rendszerek esetében - eddigi hazai vizsgálatok eredményei alapján - 1,0 fölötti értéket vesz fel, ami egységnyi területre vetített össz-biomassza többlethozamot jelent a köztesnövény nélküli erdőfelújításhoz képest. Ennek oka a köztesnövény jelenléte mellett az, hogy a tapasztalatok szerint az agroerdészettel megtámogatott erdőfelújításban a facsemeték megmaradási aránya és növekedési üteme kedvezőbb a köztesnövény nélküli telepítéshez képest. Az aszályos időjárás jelentős hatással bír az állományok állapotában és mikroklimatikus paramétereiben mért különbségekre a két különböző gyakorlat esetében (Vityi, et al. 2018). További eltérés mutatkozik a vadkárban, mivel a köztestermesztéses növénykultúra a tapasztalatok szerint csökkentheti ennek mértékét. Ezeket a faktorokat kizárva csupán a köztes növény hozama határozza meg a LER-t. Tekintettel az erdőfelújítás sikerességében tapasztalt jelentős különbségekre, a becslés további pontosítása érdekében a jövőben a fahozambeli különbség vizsgálatára is kiterjesztjük a számításokat.

\section{Köszönetnyilvánítás}

A kutatást az EFOP-3.6.2 - 16 -2017 - 00010 - Ring 2017 és az EFOP-3.6.2 - 16 2017 - 00018 - Termeljünk együtt a természettel - Az agrárerdészet, mint kitörési lehetőség című projektek támogatták.

\section{Irodalomjegyzék}

Abdul K. (2013): Comparative study of different densities of poplar in wheat based agroforestry system punjab,<https://www.researchgate.net/publication/28346983_COMPARATIVE_STUDY_OF_ 


\section{DIFFERENT_DENSITIES_OF_POPLAR_IN_WHEAT_BASED_AGROFORESTRY_SYST EM_IN_CENTRAL_PUNJAB>}

Abdullahi I. N., Anyaegbu P. O. (2017): The performance of Soybean using Moringa as alley to improve soil productivity in North-Central Nigeria, <https://academicjournals.org/journal/AJAR/article-full-text/E3C337B63613>

Briggs, S. (2015): A farmers perspective on Agroforestry, $<$ https://www.nature.scot/sites/default/files/2017-12/Seminar\%20Presentation\%20-

$\% 20$ Edinburgh\%20-\%20June\%202015\%20-

\%20Agroforestry\%20and\%20sustainable\%20intensification\%20-\%20Stephen\%20Briggs.pdf>

C. Dupraz, G. Talbot, J. Possoz, A. Querné (2010): Agroforesterier et changement climatique. Journée Agroforesterie. Toulouse, 16. Juin 2010.

Daniel N., Patrick N. (2017): Assessing the land equivalent ratio (LER) of maize (Zea mays L.) intercropped with Rhizobium inoculated soybean (Glycine max [L.] Merr.) at various P and K levels, ISSN:

2220-6655, <https://www.researchgate.net/publication/315834117_Assessing_the_land_equivalent_ratio_ LER_of_maize_Zea_mays_L_intercropped_with_Rhizobium_inoculated_soybean_Glycine_m ax_L_Merr_at_various_P_and_K_levels>

Dupraz C, Burgess PJ, Gavaland A, Graves AR, Herzog F, Incoll LD, Jackson N, Keesman K, Lawson G, Lecomte I, Mantzanas K, Mayus M, Palma J, Papanastasis V, Paris P, Pilbeam DJ, Reisner Y, van Noordwijk M, Vincent G, van der Werf W (2005) SAFE (Silvoarable Agroforestry for Europe) Synthesis Report. SAFE Project.

Erdővagyon és erdőgazdálkodás Magyarországon 2016-ban. Nébih, 2016

Gál J. 1963: A mezőgazdasági terméshozamok növekedése az erdősávok védelmében. In: Erdészettudományi Közlemények 1963. 1-2 pp41-83

IAASTD (International Assessment of Agricultural Knowledge, Science and Technology for Development) 2009: Agriculture at a Crossroads. Global report.

Jonsson R, Blujdea VNB, Fiorese G, Pilli R, Rinaldi F, Baranzelli C, Camia A (2018). Outlook of the European forest-based sector: forest growth, harvest demand, wood-product markets, and forest carbon dynamics implications. iForest 11: 315-328. - doi: 10.3832/ifor2636-011 [online 201804-18]

Kovács K ., Vityi A.(2017): Erdőtelepítés támogatása agroerdészeti rendszerekkel, In: Bidló, A; Facskó, F (szerk.), Soproni Egyetem Erdőmérnöki Kar VI. Kari Tudományos Konferencia : a konferencia előadásainak és posztereinek kivonatai, Sopron, Magyarország : Soproni Egyetem Kiadó, (2017) pp. 81-84. , 4 p.

KSH (2018): A fontosabb növények vetésterülete, http://www.ksh.hu/docs/hun/xftp/gyor/vet/vet1806.pdf

Suliman A., Ahmed M. (2012): Assessing the Land Equivalent Ratio (LER) of Two Leguminous Pastures (CLITORIA and SIRATRO) Intercropping at Various Cultural Practices and Fencing at ZALINGEI -Western Darfur State -Sudan, ISSN 2225-7217, $<$ https://www.researchgate.net/publication/285538108_Assessing_the_Land_Equivalent_Ratio _LER_of_Two_Leguminous_Pastures_CLITORIA_and_SIRATRO_Intercropping_at_Various _Cultural_Practices_and_Fencing_at_ZALINGEI_-Western_Darfur_State_-Sudan>

Vityi Andrea - Kiss Szigeti Nóra - Dr. Marosvölgyi Béla (2018): Innováció és együttmüködés az agroerdészetben. Előadás. Permakultúra, Alkalmazkodó Gyümölcsészet, Agroerdészet Konferencia, 2018.01.25-26., Budapest, SZIE

Vityi, A., Kovács K. (2018): Improve the efficiency of afforestation by the use of alley cropping system pp. 457-461. , 5 p. In: Nuria, Ferreiro-Domínguez; María, Rosa Mosquera-Losada (szerk.) Proceedings of the 4th European Agroforestry Conference : Agroforestry as Sustainable Land UseNijmegen, Hollandia : European Agroforestry Federation, (2018) p. 549

Wood products - production and trade. Agriculture, forestry and fishery statistics. Eurostat, 2018. ISBN 978-92-79-75764-8 